\title{
Profesor Teresa Czyż
}

Profesor Teresa Czyż urodziła się 1 lipca 1938 r. w Poznaniu. Jest $z$ wykształcenia geografem. Cała kariera naukowa profesor Teresy Czyż związana jest $z$ Uniwersytetem im. Adama Mickiewicza w Poznaniu. Na tej uczelni uzyskała stopnie i tytufy naukowe: magistra geografii (1960 r.), doktora nauk geograficznych (1970 r.), doktora habilitowanego nauk geograficznych w zakresie geografii ekonomicznej (1976 r.), profesora nadzwyczajnego nauk przyrodniczych (1988 r.). W 1993 r. Minister Edukacji Narodowej mianował Teresę Czyż na stanowisko profesora zwyczajnego na Uniwersytecie im. Adama Mickiewicza w Poznaniu.

Od 1962 r. profesor Teresa Czyż jest pracownikiem naukowo-dydaktycznym Uniwersytetu im. Adama Mickiewicza w Poznaniu. W Instytucie

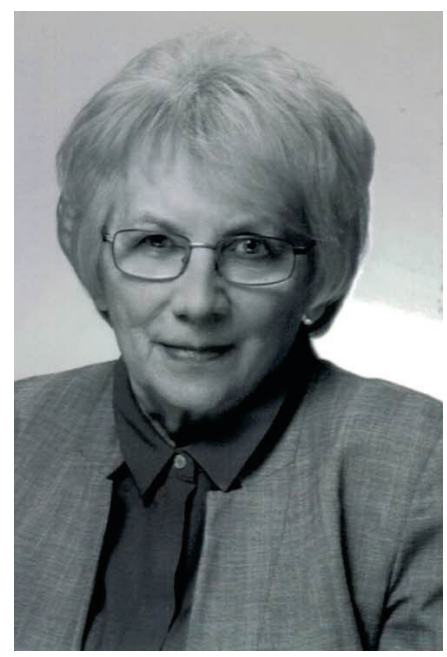
Geografii Społeczno-Ekonomicznej i Planowania Przestrzennego, po zmianie jego nazwy w 1996 r. - w Instytucie Geografii Społeczno-Ekonomicznej i Gospodarki Przestrzennej, pełniła funkcje: zastępcy dyrektora Instytutu (1987-1991), kierownika Zakładu Geografii Ekonomicznej (1981-1987), Zakładu Metod Analizy Przestrzennej (1987-1996), Zakładu Analizy Regionalnej (1996-2008). Dwukrotnie była członkiem Senatu Uniwersytetu im. Adama Mickiewicza w Poznaniu. W 1972 r. otrzymała stypendium naukowe IREX (International Research and Exchanges Board) i odbyła staż naukowy w prestiżowych uczelniach amerykańskich: Northwestern University, Ohio State University, Clark University. Była również na krótkoterminowym stażu naukowym w Reading University (Wielka Brytania) i na Uniwersytecie Moskiewskim im. Łomonosowa (Rosja).

Główne kierunki działalności naukowej profesor Teresy Czyż koncentrują się wokół trzech dziedzin: metod i modeli matematycznych w geografii, teorii regionu społeczno-ekonomicznego i regionalizacji geograficznej oraz analizy struktury regionalnej kraju. Kierunki tych badań w jej twórczości naukowej są silnie zintegrowane: opracowane nowe podejścia i rozwiązania metodologiczne stosuje $\mathrm{w}$ studiach regionalnych, opartych na rozbudowanym warsztacie empirycznym. Jej prace $z$ dziedziny modelowania matematycznego przyczyniły się do postępu metodologicznego i stanowią wkład do rozwoju szkoły naukowej nowoczesnej geografii społeczno-ekonomicznej w Polsce. Profesor Teresa Czyż jest autorem monografii z zakresu: metody analizy czynnikowej, trendu powierzchniowego i taksonomii numerycznej, które stały się wzorcem metodologicznym w badaniach geograficznych. Rozwinęła nową koncepcję strukturalno-systemową regionu społeczno-ekonomicznego, opracowała modele regionalizacji geograficznej 
z zastosowaniem metod taksonomicznych i analizy wielozmiennej, wprowadziła nowe narzędzia badania struktury systemu regionalnego $\mathrm{w}$ postaci potencjału matematycznego, łańcuchów Markowa, metody sympleksów Q, analizy głównych składowych wyższego rzędu. Równolegle z działalnością na polu metodologii badań przestrzennych profesor Teresa Czyż prowadzi studia z zakresu analizy struktury przestrzennej i regionalnej Polski, które obejmują:

1. identyfikację głównych wymiarów przestrzeni społeczno-ekonomicznej kraju w ujęciu synchronicznym i diachronicznym,

2. diagnozę struktury regionalnej kraju na podstawie powiązań społecznych i gospodarczych i ocenę jej relacji z podziałami administracyjnymi,

3. ewolucję struktury przestrzennej Polski i proces restrukturyzacji regionów,

4. weryfikację modelu wzrostu spolaryzowanego i koncepcji rdzeń-peryferie w rozwoju regionalnym Polski,

5. badania nad zmianami w regionalnym zróżnicowaniu Polski i procesem konwergencji,

6. analizę aspektów regionalnych zjawisk i procesów społecznych oraz gospodarczych wywołanych przez transformację systemową w Polsce i oddziaływanie światowego oraz europejskiego systemu społeczno-gospodarczego (bezrobocie, poziom życia, struktura przestrzenna nauki i szkolnictwa wyższego, kapitał ludzki, gospodarka oparta na wiedzy, konkurencyjność regionu, proces metropolizacji),

7. weryfikację empiryczną fazowego kształtowania się regionu terytorialnego.

Dorobek naukowy profesor Teresy Czyż obejmuje blisko 200 prac publikowanych. Jest autorem lub współautorem 8 monografii i ponad 130 artykułów naukowych, które zostały opublikowane w renomowanych czasopismach i wydawnictwach naukowych zarówno krajowych, jak i zagranicznych. Profesor Teresa Czyż brała również udział w wielu krajowych projektach badawczych, niejednokrotnie pełniąc funkcję kierownika projektu. Uczestniczyła aktywnie w ponad 50 seminariach międzynarodowych oraz kilkudziesięciu krajowych konferencjach naukowych. Prezentując wyniki swoich badań, brała udział w 6 regionalnych konferencjach Międzynarodowej Unii Geograficznej. Ponadto wygłosiła gościnne wykłady na uniwersytetach: Pennsylvania University (USA), Uniwersytet w Monachium (Niemcy), Göteborg University (Szwecja) i Kanazawa University (Japonia).

Jako nauczyciel akademicki profesor Teresa Czyż ma duże zasługi w kształceniu młodzieży oraz kadry naukowej. W ramach działalności dydaktycznej prowadziła wiele wykładów kursowych (statystyka, metody analizy przestrzennej, teoria regionu społeczno-ekonomicznego i metody regionalizacji, wstęp do geografii społeczno-ekonomicznej) oraz seminaria magisterskie dla studentów geografii i gospodarki przestrzennej Uniwersytetu im. Adama Mickiewicza w Poznaniu. Profesor Teresa Czyż wykształciła 245 magistrów i 6 doktorów. Wykładała również na Studium Doktoranckim w Instytucie Geografii i Przestrzennego Zagospodarowania Polskiej Akademii Nauk w Warszawie. Uczestniczyła jako recenzent w 15 przewodach doktorskich i 7 przewodach habilitacyjnych. Jest autorem 7 opinii w procedurach ubiegania się o tytuł profesorski. Recenzowała wiele prac 
naukowych i projektów badawczych. Jest członkiem komitetów redakcyjnych wielu czasopism naukowych.

Profesor Teresa Czyż bierze czynny udział w życiu organizacyjnym polskiej geografii i gospodarki przestrzennej. Była członkiem Komitetu Nauk Geograficznych Polskiej Akademii Nauk (1987-2011). Jest członkiem Komitetu Przestrzennego Zagospodarowania Kraju Polskiej Akademii Nauk (od 1987 r.), pełniła funkcję wiceprzewodniczącej tego Komitetu (1999-2011), od 1999 r. wchodzi w skład Prezydium Komitetu. Jest członkiem Rady Naukowej Instytutu Geografii i Przestrzennego Zagospodarowania Polskiej Akademii Nauk (od 1996 r.). Uczestniczyła w pracach sekcji specjalistycznej nauk geograficznych i oceanologii w Komitecie Badań Naukowych (w latach 1991-2003 w ramach 10 konkursów). Pełniła funkcję sekretarza Komitetu Naukowego do spraw Współpracy z Międzynarodową Unią Geograficzną (1991-1994). Aktualnie jest członkiem Regional Studies Association, Sekcja Polska.

$\mathrm{Za}$ osiągnięcia naukowe otrzymała dwie nagrody indywidualne Ministra Nauki, Szkolnictwa Wyższego i Techniki (1972, 1979) oraz dwie nagrody naukowe zespołowe Sekretarza Naukowego PAN (1980) i Ministra Edukacji Narodowej (1998). Jest odznaczona Złotym Krzyżem Zasługi i Medalem Komisji Edukacji Narodowej.

Od 2008 r. jest emerytowanym profesorem zwyczajnym Uniwersytetu im. Adama Mickiewicza w Poznaniu. Po przejściu na emeryturę profesor Teresa Czyż przejawia nadal aktywność naukową i dydaktyczną, w tym niezmienne zaangażowanie w sprawy macierzystego Wydziału Nauk Geograficznych i Geologicznych i organizację nauki polskiej.

\section{Wykaz najważniejszych publikacji naukowych:}

1. Czyż T. 1971. Zastosowanie metody analizy czynnikowej do badania ekonomicznej struktury regionalnej Polski. Prace Geograficzne, IG PAN, 92, Wrocław, ss. 114.

2. Czyż T., Chojnicki Z. 1972. Zmiany struktury regionalnej Polski w świetle przepływów towarowych w latach 1958-1966. Studia KPZK PAN, 40, Warszawa, ss. 160.

3. Czyż T., Chojnicki Z. 1973. Metody taksonomii numerycznej w regionalizacji geograficznej. PWN, Warszawa, ss. 104.

4. Czyż T., Chojnicki Z. 1976. Some problems in the application of factor analysis in geography. Geographical Analysis. An International Journal of Theoretical Geography, 6: 41-53.

5. Czyż T. 1978. Metody generalizacji układów przestrzennych. PAN, Seria Geografia, 1, Poznań, ss. 90.

6. Czyż T. 1986. Metody badania struktury regionalnej. Redakcja naukowa pracy zbiorowej. Wydawnictwo Naukowe UAM, seria Geografia, 32, Poznań, ss. 117.

7. Czyż T., Kotkowski B. 1987. Zastosowanie analizy Q do badania struktury systemu regionalnego. Przegląd Geograficzny, 59, 3: 219-258. 
8. Czyż T., Chojnicki Z. 1987. Economic growth and the standard of living of Poland's population: a regional approach. Geoforum, 18, 2: 203-212.

9. Czyż T. 1988. Problemy metodologiczne analizy przestrzennej w geografii społeczno-ekonomicznej. Redakcja naukowa pracy zbiorowej. Wydawnictwo Naukowe UAM, seria Geografia, 38, Poznań, ss. 156.

10.Czyż T., Chojnicki Z. 1992. Region, regionalisation, regionalism. [W:] G. Gorzelak, A. Kukliński (red.), Dilemmas of regional policies in Eastern and Central Europe. Regional and Local Studies, 8: 419-444. European Institute for Regional and Local Development, Warszawa.

11.Czyż T. 1995. Regional disparities and socio-economic transformation in Poland. [W:] T. Nohara, N. Akasaka (red.), The roles of metropolitan urban areas in the high-consumption society and other geographical issues of contemporary Japan and Poland. The Third Japanese-Polish Geographical Seminar, Nagoya, Japan, s. 1-28.

12.Czyż T. 1995. Regional unemployment differences in Poland. [W:] L. Lundqvist, L.O. Persson (red.), Baltic regions and Baltic links. NordREFO, Stockholm, s. 51-64.

13.Czyż T. 1996. Podstawy regionalizacji geograficznej. Redakcja naukowa pracy zbiorowej. Bogucki Wydawnictwo Naukowe, Poznań, ss. 140.

14.Czyż T., Chojnicki Z. 1997. Struktura przestrzenna nauki w Polsce. Bogucki Wydawnictwo Naukowe, Poznań, ss. 107.

15.Czyż T. 1999. Die neue territoriale Verwaltungsreform und die räumliche Struktur in Polen. Europa Regional, 01: 33-42.

16.Czyż T. 2002. Application of the potential model to the analysis of regional differences in Poland. Geographia Polonica, 75, 1: 13-24.

17.Czyż T., Chojnicki Z. 2006. Aspekty regionalne gospodarki opartej na wiedzy w Polsce. Bogucki Wydawnictwo Naukowe, Poznań, ss. 158.

18.Czyż T. 2007. Regional inequalities in Poland. [W:] K. Kobayashi, M. Kureka (red.), EU Englargement and New Europe. Hara Shobo, Japan, s. 101-114.

19.Czyż T. 2011. Conception of an urban agglomeration and metropolitan area in Poland. Geographia Polonica, 84, 2: 5-17.

20.Czyż T. 2012. Transformation of Poland's spatial economic structure in the years 1998-2008. Quaestiones Geographicae, 31, 2: 71-82.

Opracował: Pawet Churski 